\title{
Analysis of Cycle-1 Primary Science Textbooks in the Kingdom of Bahrain for Reflection of Reform
}

\author{
Faten S.M. Abdel-Hameed \\ Bahrain Teachers College, \\ University of Bahrain
}

\author{
Salah A.A. Emara \\ Bahrain Training Institute
}

\author{
Myint Swe Khine \\ Bahrain Teachers College, \\ University of Bahrain
}

\begin{abstract}
This research paper is the product of a research grant project (27/2012) that was approved and supported by the Deanship of Scientific Research at the University of Bahrain. Research papers in the field of Science education and educational reform documents have always emphasized the important role of analyzing the contents of science textbooks in improving the science teaching, learning and assessment processes. The broad objective of our analysis is to explore the effectiveness of Cycle-1 Primary Science textbooks and workbooks in terms of their reflection of the Bahrain Ministry of Education's school and curriculum reforms. When analyzing textbook contents, researchers examine the readability level, gender distribution, questioning cognitive levels and location, and graphical representations of concepts. The purpose of this paper is to quantify the type, quality and pedagogical functions of the graphical representations of the newly developed Cycle-1 primary science textbooks and the accompanying workbooks and to quantify the nature, location and cognitive levels of the texts questions as well. Twelve Science textbooks and workbooks were examined using an authordeveloped graphical analysis grid was used to examine the graphical representations. Descriptive statistical analysis was performed. Results showed domination of the non-analytic form of graphics. Maps and scale diagrams were almost absent and most of the graphs were of static nature. Analysis also showed that indigenous graphics were dominant over foreign graphics. About a third of the graphics served a specific cognitive function and were connected to the text, and most of them were captioned and indexed. An author developed questions analysis grid was used to examine the inchapter and end-of-chapter questions and problems of 6-cycle-1 science textbooks. Analysis showed the following distribution of categories of questions and problems: knowledge, 29\%; comprehension, 30.5\%; application, 12.7\%; analysis, $15.2 \%$; synthesis, $7 \%$, and evaluation, 5.5\%. Further research is undergoing to establish a connection between graphical representations and students' achievements and attitudes towards science and to analyze the cognitive level of questions in relation to their respective objectives.
\end{abstract}

\section{Introduction}

Educators have always emphasized that textbooks play a vital role in the teaching and learning processes and in promoting specific curriculum vision and type [1] [2]. For this reason, various research studies have been conducted on science- textbook analysis in the past several decades. Since textbooks are being used as major sources of information in teaching the particular subject, therefore, the quality and accuracy of the content of those texts are crucial to their educational effectiveness and to students' learning and attitudes towards science.

International organizations, such as UNESCO formulated comprehensive strategies and guidelines for analyzing texts and modes of presentations; such as the use of illustrations, photos, maps, and tables and exercises in textbooks [3].

Researchers look at the following when analyzing the science textbooks: balance between theoretical and practical knowledge, portrayal of minorities, women and gender fairness, distribution of graphical information, vocabulary load, readability, the role of textbook questions, dealing with misconceptions, and cultural and religious sensibility. A number of analytical tools have been constructed in recent years in the form of survey questionnaires, rubrics, grids, criteria, rating schemes, and image analysis protocols.

The type and quality of the graphical representations and how they interacted with the textual material in middle school science texts in the United States were quantified by Slough et al., using a developed research instrument Graphical Analysis Protocol (GAP) [4]. They reported that analytic forms of graphics were dominated in the text and one third of all graphics were decorative in nature, most graphics were static, and approximately one third were not connected to the text.

Aikenhead, stated that textbooks are mostly developed in western countries and they primarily serve their own education system and tend to carry western perspectives and culture [5]. Ninnes stated the need to promote indigenous knowledge and local culture of the society in order to make these textbooks effective in other contexts [6]. 
Lee, reported that the visual representations are commonly found in science textbooks and how they have been used is the focus of discussion among educators [7]. The author examined the extent to which changes in representations in textbooks published in the US over the past six decades. It was found that photographs are more often used than the schematic and explanatory images to promote the familiarization to students.

Ajda Kahveci, quantitatively analyzed the effectiveness of Turkish chemistry and science textbooks [8]. The author applied content analysis procedure to investigate gender equity, questioning level, science vocabulary load, and readability level and concluded that the textbooks included unfair gender representations, a considerably higher number of input-level and processing than output level questions, and high load of science terminology.

Nakiboglu et al, analyzed grade-10 school chemistry textbooks' questions in Turkey [9]. They found that most of the questions did not enable students to develop conceptual understanding and gain higher-order cognitive skills.

Davila et al, classified the end-of-chapter questions and problems of selected general chemistry textbooks in USA [10]. They found that about $70 \%$ of the questions covered low-cognitive levels, while about one third only covered the high-order thinking skills.

\section{Rationale and Purpose of the Study}

As part of the Bahrain Educational reform ourselves, we needed to perform this whole critical review of cycle-1 primary science textbooks and workbooks in order to reflect on how they are aligned with the principles and standards of the science curriculum reform and with the guiding principles of the Bahrain MOE education reform as a whole. This study is considered of a benefit to curriculum developers and teachers in producing reform-oriented science textbooks, which would help in improving the quality of science textbooks used in Bahrain.

Textbook quality has been correlated directly and indirectly to the success of education reforms and to the enhancement of students' understanding [1] [11] [12] [13]. Well designed and written textbooks are shown to help students to understand the difficult concepts and overcoming scientific misconceptions. They are also expected to raise students' interests in learning science topics and improve students' achievements in science.

According to Holliday, low-level cognitive questions reduce learning effectiveness of concepts and ideas [14]. On the other hand, Watts et al stated that higher level cognitive questions broaden students' attention [15].
Leonard highlighted the role of in-text questions in assessing students' learning [16].

In this study, we utilize an authors' developed grid to quantitatively explore the type, function and quality of the graphical representations in cycle-1 primary science textbooks. In addition, an author developed questions analysis grid is used to examine the in-chapter and end-of-chapter questions and problems of 6-cycle-1 science textbooks.

\section{Process of Developing Science Textbooks in Bahrain- Context of Study}

The school Science and Mathematics curricula reform in Bahrain was triggered by the (TIMSS) results.

As described in Abdel-Hameed, F., a Science and Mathematics curriculum development team was formed [17]. The team's job was to develop a new improved 1-12 Science and Mathematics curriculum that adopts inquiry and critical and creative thinkingbased approaches. Development included the content of textbooks, workbooks, teachers' instruction manuals as well as other learning and instructional materials.

The team started to examine various science and mathematics textbooks and accompanying

Table 1. List of textbooks under study

\begin{tabular}{|l|l|c|l|c|}
\hline No & Level & Part & Title & Pages \\
\hline 1 & Primary 1 & I & Students' Text Book & 128 \\
\hline 2 & Primary 1 & I & Students' Work Book & 40 \\
\hline 3 & Primary 1 & II & Students' Text Book & 126 \\
\hline 4 & Primary 1 & II & Students' Work Book & 33 \\
\hline 5 & Primary 2 & I & Students' Text Book & 120 \\
\hline 6 & Primary 2 & I & Students' Work Book & 52 \\
\hline 7 & Primary 2 & II & Students' Text Book & 126 \\
\hline 8 & Primary 2 & II & Students' Work Book & 53 \\
\hline 9 & Primary 3 & I & Students' Text Book & 138 \\
\hline 10 & Primary 3 & I & Students' Work Book & 54 \\
\hline 11 & Primary 3 & II & Students' Text Book & 148 \\
\hline 12 & Primary 3 & II & Students' Work Book & 54 \\
\hline
\end{tabular}

materials from international publishing companies, looking for high quality learning materials in which the content addresses the ideas students are intended to learn, as described in the modified curriculum, and the instructional modes support effective teaching and student achievement of a learning goal. McGraw-Hill Science and Mathematics K-12 package was chosen. A team of Science consultants and specialists performed, supervised and reviewed the adaptation and alignment of the Arabic versions of all learning materials with the Bahraini curriculum, with the aid of Obeikan publishing of Saudi Arabia. 
Science: A Closer Look, from McGraw-Hill Science for primary 1,2 and 3 offers students' exciting and accessible standards-based lessons,

Table 2. Graphic types with description

\begin{tabular}{|c|c|}
\hline \multicolumn{2}{|c|}{ Graph Type } \\
\hline \multicolumn{2}{|l|}{ I - Topic Area } \\
\hline Plant & $\begin{array}{l}\text { A plant photo or drawing of indigenous (local Arabic } \\
\text {-from the Gulf-or Bahraini) or foreign origin } \\
\text { (outside the Arabic world) }\end{array}$ \\
\hline Animal & $\begin{array}{l}\text { An animal photo or drawing of indigenous (local } \\
\text { Arabic -from the Gulf - or Bahraini) or foreign } \\
\text { origin (outside the Arabic world) }\end{array}$ \\
\hline Human & A human photo or drawing, female or male \\
\hline Environmental Science & $\begin{array}{l}\text { An environmental photo or drawing of indigenous } \\
\text { (local Arabic-from the Gulf-or Bahraini) or } \\
\text { foreign origin (outside the Arabic world) }\end{array}$ \\
\hline General & $\begin{array}{l}\text { A general-science photo or drawing of indigenous } \\
\text { (local Arabic-from the Gulf-or Bahraini) or } \\
\text { foreign origin (outside the Arabic world) }\end{array}$ \\
\hline Earth Science & $\begin{array}{l}\text { An earth science photo or drawing of indigenous } \\
\text { (local Arabic-from the Gulf- or Bahraini) or } \\
\text { foreign origin (outside the Arab world) }\end{array}$ \\
\hline Physical Science & $\begin{array}{l}\text { A chemistry or physics photo or drawing of } \\
\text { indigenous (local Arabic - from the Gulf - or } \\
\text { Bahraini) or foreign origin (outside the Arabic world) }\end{array}$ \\
\hline \multicolumn{2}{|l|}{ II-Form } \\
\hline Photograph & Photograph only \\
\hline Drawing & All features are shown in details \\
\hline Map & $\begin{array}{l}\text { Geographical features with spatial relation to other } \\
\text { objects }\end{array}$ \\
\hline Table & Cells, rows and columns \\
\hline Flow chart & Arrows or numbers indicating stages \\
\hline Graph & Relationships, statistical bar or pie graphs \\
\hline \multicolumn{2}{|c|}{ III - Ethnic representation } \\
\hline Indigenous & Local photograph (gulf states or Arabic)or drawing \\
\hline Foreign & Non-local photograph or drawing \\
\hline \multicolumn{2}{|c|}{ IV - Gender representation } \\
\hline Female & Female human photograph or drawing \\
\hline Male & Male human photograph or drawing \\
\hline \multicolumn{2}{|l|}{ V-Indexing } \\
\hline None & Photograph or drawing is not mentioned in text \\
\hline indexed & Photograph or drawing is mentioned in text \\
\hline \multicolumn{2}{|l|}{ VI- Captioning } \\
\hline No caption & No title or description under graph or drawing \\
\hline captioned & $\begin{array}{l}\text { A title or description is written under graph or } \\
\text { drawing }\end{array}$ \\
\hline \multicolumn{2}{|l|}{ VII- Quality } \\
\hline Dynamic & $\begin{array}{l}\text { Use series of images to show change over time in } \\
\text { graph or drawing }\end{array}$ \\
\hline static & No change with time in graph or drawing \\
\hline \multicolumn{2}{|l|}{ VIII- Function } \\
\hline Decorative & $\begin{array}{l}\text { Does not support text, if taken out does not cause any } \\
\text { difference in understanding of the written text }\end{array}$ \\
\hline Related to Text & $\begin{array}{l}\text { Important to text written, if taken out will affect } \\
\text { understanding of text }\end{array}$ \\
\hline
\end{tabular}

engaging activities which promote curiosity and foster the development of science inquiry skills. Through a consistent and structured learning cycle (Engage, Explore, Explain, Evaluate and Elaborate), students confidently build upon their experiences to develop a lifelong understanding of science concepts in the following fields: Life sciences, Physical sciences, Earth sciences and Environmental sciences.

\section{Methodology}

\subsection{Sample}

The sample consisted of all Cycle 1 Science Students' Text-Books and Workbooks adopted in all government schools in the Kingdom of Bahrain for the graphical representations analysis. For questions nature \& cognitive levels analyses, only 6-textbooks were considered. Table 1 lists the titles that were covered in this study.

\subsection{Research Tools}

All graphics in the selected books were coded and analyzed with the researchers' developed Graphical Analysis grid.

\section{Table 3. Classifying End-of-Chapters and In-} Chapters Questions

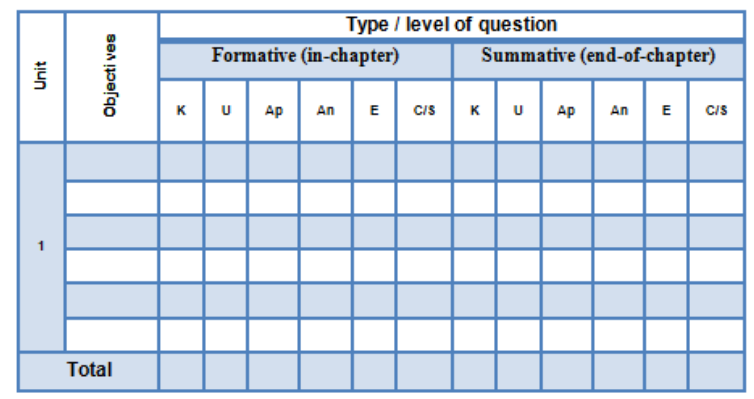

K= Knowledge, $\mathrm{U}=$ Understanding, Ap = Applications, An= Analysis, $\mathrm{E}=$ Evaluation, $\mathrm{C} / \mathrm{S}=\mathrm{Creativity} / \mathrm{Synthesis}$

We looked for the graphs' form, function, topic area, quality, ethnic representation, gender representation, type and relation to text. Table 2 lists the categories of graphics with clear descriptions, as was described in Abdel-Hameed, F. [17].

For analysis of questions, the six Science textbooks were examined using an author-developed questions analysis grid, shown in Table 3.

\subsection{Analysis Procedures}

As described in Abdel-Hameed, F., following the development of the graphical analysis instrument, a coding key was used to establish a common understanding among the researchers [17]. The data for each category were tabulated for each chapter in each textbook and workbook on a paper matrix. The data were then entered into an excel file and descriptive statistics for each variable were calculated. The grid was validated previously as described in Abdel-Hameed, F., by two science education specialists [17]. In order to enhance the validity and reliability of the analysis procedure, two well experienced science curriculum specialists helped in performing the initial classification of the graphical representations, then the main author reviewed and re-entered the data into the excel grid for descriptive statistical calculations.

Questions were classified using the original and revised Bloom's taxonomies of educational objectives, as it is based on a clear hierarchical cognitive framework from simple to complex and 
from concrete to abstract [18] [19]. Our analysis focused on the in-chapter and end-of-chapter questions and problems. In order to ensure the reliability of our classification of questions, we did the following: agreed upon an initial scheme based on the analysis of randomly selected questions, then both authors and an assistant independently analyzed one randomly selected chapter questions and classified them. Results were then compared, cases of disagreements were discussed, and a final category code was agreed upon. We repeated this process until we reached about $90 \%$ agreement. Then each researcher analyzed and categorized the assigned chapters/texts questions independently.

\section{Results and Data Interpretation}

\subsection{Graphical Representations' Analysis}

In the following section, overall statistics regarding the number of pages and graphics analyzed, as well as results by research question according to the overall categories of: form, function, quality, ethnic representation and gender representation are reported for every grade level of cycle1's science texts and workbooks.

About 2,551 graphical representations were analyzed in the 12- textbooks and workbooks (two parts for every grade level). Illustrations covering all science topic areas were examined to answer the first research question in this study;

(1)What are the frequencies of the graphics among the science topic areas?

Table 4. Frequencies of graphics in various topic areas for Cycle-1 primary Science textbooks and workbooks

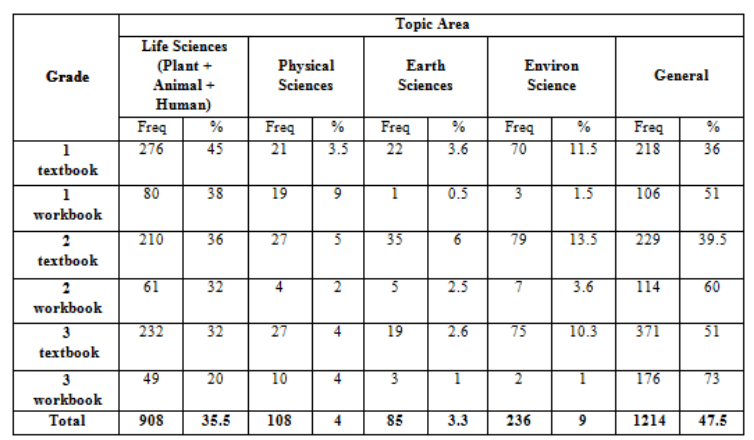

As shown in Table 3, for grade 1 students' text books: $45 \%$ of the graphics covered life sciences, followed by $36 \%$ for general sciences, $11 \%$ for environmental science, and $3.5 \%$ for both earth and physical sciences. The largest percentage of graphics covered life sciences, as it is the most common topic area in this age and grade level. For grade 1 work books, general sciences graphics represented the highest percentages $(51 \%)$, followed by life science (38\%), then physical science (9\%) and environmental sciences (1.5\%), and earth sciences came last with a percentage of $(0.5 \%)$. For grade 2 students' text books, the same trend was found, as shown in Table 3, with $39.5 \%$ of the graphics covering general sciences, $36 \%$ life sciences, $13.5 \%$ environmental sciences, $6 \%$ earth science and $5 \%$ physical sciences. For grade 2 work books, the trend was as follows: $60 \%$ of the graphics covered general sciences, $32 \%$ life sciences, $3.6 \%$ environmental sciences, $2.5 \%$ earth science and $2 \%$ physical sciences. Finally, for grade 3 students' text books: $51 \%$ of the graphics covered general sciences, $32 \%$ life sciences, $10.3 \%$ environmental sciences, $2.5 \%$ earth science and $2 \%$ physical sciences. For grade 3 work books: $73 \%$ of the graphics covered general sciences, $20 \%$ life sciences, $4 \%$ physical sciences, $1 \%$ environmental and earth sciences.

To answer the second research question:

(2)What is the distribution of the various forms of graphical representations?

The graphics in the 12 cycle- 1 primary textbooks and workbooks were examined and broken down to photographs, drawings, maps, tables, flow charts, graphs and hybrids, the results are shown in table 5 for grades 1, 2 and 3 textbooks, and in Table 6 for workbooks.

Table 5. Distribution of the forms of graphical representations for grades: 1, 2 and 3 textbooks

\begin{tabular}{|c|c|c|c|c|c|c|c|c|}
\hline \multirow{2}{*}{ Form } & \multicolumn{6}{|c|}{ Grade } & \multicolumn{2}{|c|}{ Total } \\
\cline { 2 - 9 } & \multicolumn{2}{|c|}{$\mathbf{1}$} & \multicolumn{2}{|c|}{$\mathbf{2}$} & \multicolumn{2}{|c|}{3} & \multicolumn{2}{|c|}{} \\
\cline { 2 - 9 } & Freq & $\%$ & Freq & $\%$ & Freq & $\%$ & Freq & $\%$ \\
\hline Photograph & 568 & 93.6 & 532 & 91.7 & 647 & 89.3 & $\mathbf{1 7 4 7}$ & $\mathbf{9 1 . 5}$ \\
\hline Drawing & 29 & 4.8 & 32 & 5.5 & 49 & 6.7 & $\mathbf{1 1 0}$ & $\mathbf{5 . 7}$ \\
\hline Table & 3 & 0.5 & 5 & 0.9 & 12 & 1.7 & $\mathbf{2 0}$ & $\mathbf{1}$ \\
\hline Map & 1 & 0.15 & 2 & 0.35 & 6 & 0.85 & $\mathbf{9}$ & $\mathbf{0 . 5}$ \\
\hline Flow chart & 1 & 0.15 & 2 & 0.35 & 3 & 0.45 & $\mathbf{6}$ & $\mathbf{0 . 3}$ \\
\hline Graph & 0 & 0 & 1 & 0.2 & 2 & 0.35 & $\mathbf{3}$ & $\mathbf{0 . 1 6}$ \\
\hline hybrid & 5 & 0.8 & 6 & 1 & 5 & 0.6 & $\mathbf{1 6}$ & $\mathbf{0 . 8 4}$ \\
\hline Total & $\mathbf{6 0 7}$ & $\mathbf{1 0 0}$ & $\mathbf{5 8 0}$ & $\mathbf{1 0 0}$ & $\mathbf{7 2 4}$ & $\mathbf{1 0 0}$ & $\mathbf{1 9 1 1}$ & $\mathbf{1 0 0}$ \\
\hline
\end{tabular}


Table 6. Distribution of the forms of graphical representations for grades: 1,2 and 3 workbooks

\begin{tabular}{|c|c|c|c|c|c|c|c|c|}
\hline \multirow{2}{*}{ Form } & \multicolumn{6}{|c|}{ Grade } & \multicolumn{2}{|c|}{ Total } \\
\cline { 2 - 8 } & \multicolumn{2}{|c|}{$\mathbf{1}$} & \multicolumn{2}{|c|}{$\mathbf{2}$} & \multicolumn{2}{|c|}{3} \\
\cline { 2 - 8 } & Freq & $\%$ & Freq & $\%$ & Freq & $\%$ & Freq & $\%$ \\
\hline Photograph & 201 & 96.2 & 183 & 96 & 211 & 88 & 595 & $\mathbf{9 3}$ \\
\hline Drawing & 3 & 1.5 & 5 & 2.5 & 17 & 7 & ${ }^{25}$ & $\mathbf{4}$ \\
\hline Table & 5 & 2.4 & 3 & 1.5 & 6 & 2.5 & $\mathbf{1 4}$ & 2.1 \\
\hline Map & 0 & 0 & 0 & 0 & 0 & 0 & $\mathbf{0}$ & $\mathbf{0}$ \\
\hline Flow chart & 0 & 0 & 0 & 0 & 3 & 1.25 & 3 & $\mathbf{0 . 4 5}$ \\
\hline Graph & 0 & 0 & 0 & 0 & 0 & 0 & $\mathbf{0}$ & $\mathbf{0}$ \\
\hline hybrid & 0 & 0 & 0 & 0 & ${ }^{3}$ & 1.25 & ${ }^{3}$ & $\mathbf{0 . 4 5}$ \\
\hline Total & $\mathbf{2 0 9}$ & $\mathbf{1 0 0}$ & $\mathbf{1 9 1}$ & $\mathbf{1 0 0}$ & $\mathbf{2 4 0}$ & $\mathbf{1 0 0}$ & $\mathbf{6 4 0}$ & $\mathbf{1 0 0}$ \\
\hline
\end{tabular}

Results showed that: in grade 1 textbooks, both part I and II, photographs were the most common form of graphics at $93.6 \%$, while drawings came second at $4.8 \%$, tables at $0.5 \%$, hybrids at $0.8 \%$, maps at $0.15 \%$, flow charts at $0.15 \%$, and graphs at $0 \%$. In grade 1 work-books, both part I and II, photographs were the most common form of graphics at $96.2 \%$, with tables at $2.4 \%$, drawings at $1.5 \%$, flow charts at $0 \%$, maps at $0 \%$, hybrids at $0 \%$, and graphs at $0 \%$. In grade 2 textbooks, both part I and II, the same trend was observed, photographs were the most common form of graphics at $91.7 \%$, with drawings at $5.5 \%$, hybrids at $1 \%$, tables at $0.9 \%$, flow chart at $0.35 \%$, maps at $0.35 \%$, and graphs at $0.2 \%$. In grade 2 work-books, both part I and II, photographs were the most common form of graphics at $96 \%$, with tables at $2.5 \%$, drawings at $1.5 \%$, flow charts at $0 \%$, and maps, graphs and hybrids at $0 \%$. In grade 3 textbooks, both part I and II, photographs were the most common form of graphics at $89.3 \%$, with drawings at $6.7 \%$, tables at $1.7 \%$, maps at $0.85 \%$, hybrids at $0.6 \%$, flow charts at $0.45 \%$, and graphs at $0.35 \%$. In grade 3 work-books, both part I and II, photographs were the most common form of graphics at $88 \%$, with drawings at $7 \%$, tables at $2.5 \%$, flow charts and hybrids at $1.25 \%$, and maps and graphs at $0 \%$.

The third question stated that:

(3) What is the distribution of the forms of graphical representations in the topic areas in the sampled primary science textbooks and work-books for cycle1?

Summaries of the distribution results for this research question are given in Tables 7 and 8 for cycle-1 textbooks and workbooks respectively, which show that photographs dominate all topic areas in all grade levels.
Table 7. Distribution of the forms of graphical representations in topic areas for textbooks

\begin{tabular}{|c|c|c|c|c|c|c|c|c|c|c|c|c|}
\hline \multirow{4}{*}{$\begin{array}{l}\text { Topic } \\
\text { Area }\end{array}$} & \multicolumn{12}{|c|}{ Grade } \\
\hline & \multicolumn{4}{|c|}{1} & \multicolumn{4}{|c|}{2} & \multicolumn{4}{|c|}{3} \\
\hline & \multicolumn{2}{|c|}{ Photograph } & \multicolumn{2}{|c|}{ Drawing } & \multicolumn{2}{|c|}{ Photograph } & \multicolumn{2}{|c|}{ Drawing } & \multicolumn{2}{|c|}{ Photograph } & \multicolumn{2}{|c|}{ Drawing } \\
\hline & 1 & $\mathrm{~F}$ & 1 & $\mathrm{~F}$ & 1 & $\mathrm{~F}$ & 1 & $\mathrm{~F}$ & 1 & $\mathrm{~F}$ & 1 & $\mathrm{~F}$ \\
\hline Life sci & 134 & 111 & 5 & 3 & 65 & 111 & 11 & 2 & 63 & 135 & 7 & 6 \\
\hline $\begin{array}{c}\begin{array}{c}\text { Phys } \\
\text { sci }\end{array}\end{array}$ & 26 & 1 & 1 & 0 & 4 & 2 & 1 & 0 & 0 & 3 & 0 & 0 \\
\hline $\begin{array}{c}\text { Earth } \\
\text { sci }\end{array}$ & 20 & 2 & 0 & 0 & 10 & 18 & 3 & 0 & 5 & 16 & 0 & 0 \\
\hline Envi Sci & 26 & 52 & 0 & 0 & 19 & 50 & 5 & 0 & 11 & 59 & 0 & 6 \\
\hline Gen Sci & 206 & 5 & 6 & 2 & 221 & 10 & 5 & 0 & 244 & 15 & 11 & 2 \\
\hline Total & 412 & 175 & 12 & 5 & 319 & 191 & 25 & 2 & 323 & 228 & 18 & 14 \\
\hline
\end{tabular}

(a) Grade 1 textbooks

\begin{tabular}{|c|c|c|c|c|c|c|c|c|c|c|c|c|}
\hline \multirow{3}{*}{ Form } & \multicolumn{12}{|c|}{ Grade 1} \\
\hline & \multicolumn{2}{|c|}{ Life Sciences } & \multicolumn{2}{|c|}{$\begin{array}{l}\text { Physical } \\
\text { Sciences }\end{array}$} & \multicolumn{2}{|c|}{ Earth Sciences } & \multicolumn{2}{|c|}{$\begin{array}{l}\text { Environ } \\
\text { Science }\end{array}$} & \multicolumn{2}{|c|}{ General } & \multicolumn{2}{|c|}{ Total } \\
\hline & Freq & $\%$ & Freq & $\%$ & Freq & $\%$ & Freq & $\%$ & Freq & $\%$ & Freq & $\%$ \\
\hline Photog. & 77 & 99 & 18 & 100 & 1 & 100 & 3 & 100 & 102 & 98 & 201 & 98.5 \\
\hline Draw. & 1 & 1 & 0 & 0 & 0 & 0 & 0 & 0 & 2 & 2 & 3 & 1.5 \\
\hline Total & 78 & 100 & 18 & 100 & 1 & 100 & 3 & 100 & 104 & 100 & 204 & 100 \\
\hline
\end{tabular}

(b) Grade 2 textbooks

\begin{tabular}{|c|c|c|c|c|c|c|c|c|c|c|c|c|}
\hline \multirow{3}{*}{ Form } & \multicolumn{10}{|c|}{ Grade 2 } \\
\cline { 2 - 15 } & \multicolumn{2}{|c|}{$\begin{array}{c}\text { Life Sciences } \\
\text { Sciences }\end{array}$} & \multicolumn{2}{|c|}{$\begin{array}{c}\text { Earth } \\
\text { Sciences }\end{array}$} & \multicolumn{2}{|c|}{$\begin{array}{c}\text { Environment } \\
\text { al Science }\end{array}$} & \multicolumn{2}{|c|}{ General } & \multicolumn{2}{|c|}{ Total } \\
\cline { 2 - 14 } & Freq & $\%$ & Freq & $\%$ & Freq & $\%$ & Freq & $\%$ & Freq & $\%$ & Freq & $\%$ \\
\hline Photog & $\mathbf{1 8 9}$ & $\mathbf{9 2}$ & $\mathbf{1 8}$ & $\mathbf{7 8}$ & $\mathbf{3 0}$ & $\mathbf{9 7}$ & $\mathbf{7 4}$ & $\mathbf{9 6}$ & $\mathbf{2 2 1}$ & $\mathbf{9 7}$ & $\mathbf{5 3 2}$ & $\mathbf{9 4 . 3}$ \\
\hline Draw. & $\mathbf{1 7}$ & $\mathbf{8}$ & $\mathbf{5}$ & $\mathbf{2 2}$ & $\mathbf{1}$ & $\mathbf{3}$ & $\mathbf{3}$ & $\mathbf{4}$ & $\mathbf{6}$ & $\mathbf{3}$ & $\mathbf{3 2}$ & $\mathbf{5 . 7}$ \\
\hline Total & $\mathbf{2 0 6}$ & $\begin{array}{c}10 \\
0\end{array}$ & $\mathbf{2 3}$ & $\mathbf{1 0 0}$ & $\mathbf{3 1}$ & $\begin{array}{c}10 \\
0\end{array}$ & $\mathbf{7 7}$ & $\mathbf{1 0 0}$ & $\mathbf{2 2 7}$ & $\mathbf{1 0 0}$ & $\mathbf{5 6 4}$ & $\mathbf{1 0 0}$ \\
\hline
\end{tabular}

(c) Grade 3 textbooks

\begin{tabular}{|c|c|c|c|c|c|c|c|c|c|c|c|c|}
\hline \multirow{3}{*}{ Form } & \multicolumn{12}{|c|}{ Grade 3} \\
\hline & \multicolumn{2}{|c|}{ Life Sciences } & \multicolumn{2}{|c|}{$\begin{array}{l}\text { Physical } \\
\text { Sciences }\end{array}$} & \multicolumn{2}{|c|}{$\begin{array}{c}\text { Earth } \\
\text { Sciences }\end{array}$} & \multicolumn{2}{|c|}{$\begin{array}{l}\text { Environment } \\
\text { al Science }\end{array}$} & \multicolumn{2}{|c|}{$\begin{array}{l}\text { General } \\
\end{array}$} & \multicolumn{2}{|c|}{ Total } \\
\hline & $\mathrm{Fq}$ & $\%$ & $\mathrm{Fq}$ & $\%$ & $\mathrm{Fq}$ & $\%$ & $\mathrm{Fq}$ & $\%$ & $\mathrm{Fq}$ & $\%$ & $\mathrm{Fq}$ & $\%$ \\
\hline Photog. & 206 & 93 & 22 & 88 & 15 & 88 & 65 & 94 & 342 & 95 & 647 & 93 \\
\hline Drawing & 16 & 7 & 3 & 12 & 2 & 12 & 4 & 6 & 19 & 5 & 49 & 7 \\
\hline Total & 222 & 100 & 25 & 100 & 17 & 100 & 69 & 100 & 361 & 100 & 696 & 100 \\
\hline
\end{tabular}

Table 8. Distribution of the forms of graphical representations in topic areas for workbooks:

\begin{tabular}{|c|c|c|c|c|c|c|c|c|c|c|c|c|}
\hline \multirow{4}{*}{$\begin{array}{l}\text { Topic } \\
\text { Area }\end{array}$} & \multicolumn{12}{|c|}{ Grade } \\
\hline & \multicolumn{4}{|c|}{1} & \multicolumn{4}{|c|}{2} & \multicolumn{4}{|c|}{3} \\
\hline & \multicolumn{2}{|c|}{ Photograph } & \multicolumn{2}{|c|}{ Draw } & \multicolumn{2}{|c|}{ Photograph } & \multicolumn{2}{|c|}{ Drawing } & \multicolumn{2}{|c|}{ Photograph } & \multicolumn{2}{|c|}{ Drawing } \\
\hline & 1 & $\mathrm{~F}$ & 1 & $\mathrm{~F}$ & 1 & $\mathrm{~F}$ & 1 & $\mathrm{~F}$ & 1 & $\mathrm{~F}$ & 1 & $\mathrm{~F}$ \\
\hline Life sci & 48 & 22 & 2 & 0 & 22 & 27 & 0 & 0 & 16 & 29 & 0 & 0 \\
\hline $\begin{array}{l}\text { Phys } \\
\text { sci }\end{array}$ & 19 & 0 & 0 & 0 & 0 & 0 & 0 & 0 & 0 & 0 & 0 & 0 \\
\hline $\begin{array}{c}\text { Earth } \\
\text { sci }\end{array}$ & 1 & 0 & 0 & 0 & 5 & 0 & 0 & 0 & 0 & 0 & 0 & 0 \\
\hline Envi Sci & 3 & 0 & 0 & 0 & 0 & 7 & 0 & 0 & 0 & 0 & 0 & 0 \\
\hline Gen & 106 & 0 & 0 & 0 & 107 & 0 & 1 & 0 & 172 & 2 & 2 & 0 \\
\hline Total & 177 & 22 & 2 & 0 & 134 & 34 & 1 & 0 & 188 & 31 & 2 & 0 \\
\hline
\end{tabular}


(a) Grade 1 workbooks

\begin{tabular}{|c|c|c|c|c|c|c|c|c|c|c|c|c|}
\hline \multirow{3}{*}{ Form } & \multicolumn{10}{|c|}{ Grade 1 } \\
\cline { 2 - 14 } & \multicolumn{2}{|c|}{ Life Sciences } & \multicolumn{2}{|c|}{ Physical Sciences } & \multicolumn{2}{|c|}{ Earth Sciences } & \multicolumn{2}{|c|}{$\begin{array}{c}\text { Environ. } \\
\text { Science }\end{array}$} & \multicolumn{2}{|c|}{ General } & \multicolumn{2}{|c|}{ Total } \\
\cline { 2 - 14 } & ${ }^{\mathrm{Fq}}$ & $\%$ & ${ }^{\mathrm{Fq}}$ & $\%$ & ${ }^{\mathrm{Fq}}$ & $\%$ & ${ }^{\mathrm{Fq}}$ & $\%$ & ${ }^{\mathrm{Fq}}$ & $\%$ & ${ }^{\mathrm{Fq}}$ & $\%$ \\
\hline Photogr & 255 & 93.5 & 17 & 85 & 18 & 90 & 66 & 97 & 212 & 98 & 568 & 95 \\
\hline Drawing & 18 & 6.5 & 3 & 15 & 2 & 10 & 2 & 3 & 4 & 2 & 29 & 5 \\
\hline Total & 273 & 100 & 20 & 100 & 20 & 100 & 68 & 100 & 216 & 100 & 597 & 100 \\
\hline
\end{tabular}

(b) Grade 2 work-books

\begin{tabular}{|c|c|c|c|c|c|c|c|c|c|c|c|c|}
\hline \multirow{2}{*}{ Form } & \multicolumn{10}{|c|}{ Grade 2 } \\
\cline { 2 - 14 } & \multicolumn{2}{|c|}{ Life Sciences } & \multicolumn{1}{|c|}{ Physical Sciences } & \multicolumn{2}{|c|}{ Earth Sciences } & \multicolumn{2}{|c|}{$\begin{array}{c}\text { Environm } \\
\text { Science }\end{array}$} & \multicolumn{2}{|c|}{ General } & \multicolumn{3}{|c|}{ Total } \\
\cline { 2 - 14 } & $\mathrm{Fq}$ & $\%$ & $\mathrm{Fq}$ & $\%$ & $\mathrm{Fq}$ & $\%$ & $\mathrm{Fq}$ & $\%$ & ${ }^{\mathrm{Fq}}$ & $\%$ & $\mathrm{Fq}$ & $\%$ \\
\hline Photog. & 57 & 95 & 4 & 100 & 5 & 100 & 7 & 100 & 110 & 98 & 183 & 97.3 \\
\hline Draw & 3 & 5 & 0 & 0 & 0 & 0 & 0 & 0 & 2 & 2 & 5 & 2.7 \\
\hline Total & 60 & 100 & 4 & 100 & 5 & 0 & 7 & 100 & 112 & 100 & 188 & 100 \\
\hline
\end{tabular}

(c) Grade 3 work-books

\begin{tabular}{|c|c|c|c|c|c|c|c|c|c|c|c|c|}
\hline \multirow{3}{*}{ Form } & \multicolumn{12}{|c|}{ Grade 3} \\
\hline & \multicolumn{2}{|c|}{ Life Sciences } & \multicolumn{2}{|c|}{$\begin{array}{l}\text { Physical } \\
\text { Sciences }\end{array}$} & \multicolumn{2}{|c|}{$\begin{array}{c}\text { Earth } \\
\text { Sciences }\end{array}$} & \multicolumn{2}{|c|}{$\begin{array}{l}\text { Environm } \\
\text { Science }\end{array}$} & \multicolumn{2}{|c|}{ General } & \multicolumn{2}{|c|}{ Total } \\
\hline & $\mathrm{Fq}$ & $\%$ & $\mathrm{Fq}$ & $\%$ & $\mathrm{Fq}$ & $\%$ & $\mathrm{Fq}$ & $\%$ & $\mathrm{Fq}$ & $\%$ & $\mathrm{Fq}$ & $\%$ \\
\hline Photog. & 39 & 87 & 6 & 75 & $\mathbf{0}$ & $\mathbf{0}$ & 0 & $\mathbf{0}$ & 161 & 94 & 211 & 92.5 \\
\hline Draw. & 5 & 23 & 2 & 25 & 0 & 0 & 0 & 0 & 10 & 6 & 17 & 7.5 \\
\hline Total & 44 & 100 & 8 & 100 & 3 & $\mathbf{0}$ & 2 & $\mathbf{0}$ & 171 & 100 & 228 & 100 \\
\hline
\end{tabular}

The fourth question deals with the gender representations:

(4) What is the distribution of the gender representations of graphics in the sampled primary science textbooks and work-books for cyclel?

The answer to the above question is summarized in Table 9, which shows that male representations dominated both photographs and drawings, ranging from $50 \%$ to $70 \%$ as shown in the Table below:

Table 9. Distribution of the gender representations of graphics for textbooks and work-books

\begin{tabular}{|c|c|c|c|c|}
\hline \multirow{2}{*}{ Grade } & \multicolumn{4}{|c|}{ Gender } \\
\cline { 2 - 5 } & \multicolumn{2}{|c|}{ Photograph } & \multicolumn{2}{c|}{ Drawing } \\
\cline { 2 - 5 } & $\mathrm{M}^{*}$ & $\mathrm{~F}^{* *}$ & $\mathrm{M}^{*}$ & $\mathrm{~F}^{* *}$ \\
\hline 1 (textbook) & 83 & 31 & 5 & 2 \\
\hline 2 (textbook) & 63 & 17 & 6 & 3 \\
\hline 3 (textbook) & 99 & 27 & 8 & 3 \\
\hline 1(workbook) & 13 & 10 & 5 & 2 \\
\hline 2(workbook) & 21 & 6 & 4 & 3 \\
\hline 3(workbook) & 31 & 19 & 3 & 1 \\
\hline
\end{tabular}

$* \mathrm{M}=$ Male, ${ }^{* *} \mathrm{~F}=$ Female
Question 5 stated that:

(5) What was the ethnic representation (indigenous, foreign) of the graphics in the newly developed cycle-1 primary science textbooks and workbooks?

Ethnic representation data for both research questions are given in tables 9 and 10 for cycle-1 primary science textbooks and workbooks, respectively. We can see that the indigenous graphics dominated all grade levels in all topics of textbooks, making $60-70 \%$ of photographs and $60-$ $90 \%$ of drawings, as can be seen from Table 10 . For workbooks, indigenous graphics dominated all grade levels in all topics, making $80-90 \%$ of photographs and almost $100 \%$ of drawings, as can be seen from Table 11.

Table 10. Distribution of ethnic representations in textbooks ( $\mathrm{I}=$ Indigenous, $\mathrm{F}=$ Foreign $)$

\begin{tabular}{|c|c|c|c|c|c|c|c|c|c|c|c|c|}
\hline \multirow{4}{*}{$\begin{array}{l}\text { Topic } \\
\text { Area }\end{array}$} & \multicolumn{12}{|c|}{ Grade } \\
\hline & \multicolumn{4}{|c|}{1} & \multicolumn{4}{|c|}{2} & \multicolumn{4}{|c|}{3} \\
\hline & \multicolumn{2}{|c|}{ Photograph } & \multicolumn{2}{|c|}{ Drawing } & \multicolumn{2}{|c|}{ Photograph } & \multicolumn{2}{|c|}{ Drawing } & \multicolumn{2}{|c|}{ Photograph } & \multicolumn{2}{|c|}{ Drawing } \\
\hline & $\mathrm{I}$ & $F$ & $\mathrm{I}$ & $F$ & $\mathrm{I}$ & $F$ & $\mathrm{I}$ & $F$ & $\mathrm{I}$ & $F$ & $\mathrm{I}$ & $\mathbf{F}$ \\
\hline $\begin{array}{l}\text { Life } \\
\text { sci }\end{array}$ & 134 & 111 & 5 & 3 & 65 & 111 & 11 & 2 & 63 & 135 & 7 & 6 \\
\hline $\begin{array}{l}\text { Phys } \\
\text { sci }\end{array}$ & 26 & 1 & 1 & 0 & 4 & 2 & 1 & 0 & 0 & 3 & 0 & 0 \\
\hline $\begin{array}{l}\text { Earth } \\
\text { sci }\end{array}$ & 20 & 2 & 0 & 0 & 10 & 18 & 3 & 0 & 5 & 16 & 0 & 0 \\
\hline $\begin{array}{l}\text { Envi } \\
\text { Sci }\end{array}$ & 26 & 52 & 0 & 0 & 19 & 50 & 5 & 0 & 11 & 59 & 0 & 6 \\
\hline $\begin{array}{l}\text { Gen } \\
\text { Sci }\end{array}$ & 206 & 5 & 6 & 2 & 221 & 10 & 5 & 0 & 244 & 15 & 11 & 2 \\
\hline Total & 412 & 175 & 12 & 5 & 319 & 191 & 25 & 2 & 323 & 228 & 18 & 14 \\
\hline
\end{tabular}

Table 11. Distribution of ethnic representations in workbooks ( $\mathrm{I}=$ Indigenous, $\mathbf{F}=$ Foreign $)$

\begin{tabular}{|c|c|c|c|c|c|c|c|c|c|c|c|c|}
\hline \multirow{4}{*}{$\begin{array}{c}\text { Topic } \\
\text { Area }\end{array}$} & \multicolumn{12}{|c|}{ Grade } \\
\hline & \multicolumn{4}{|c|}{1} & \multicolumn{4}{|c|}{2} & \multicolumn{4}{|c|}{3} \\
\hline & \multicolumn{2}{|c|}{ Photograph } & \multicolumn{2}{|c|}{ Draw } & \multicolumn{2}{|c|}{ Photograph } & \multicolumn{2}{|c|}{ Drawing } & \multicolumn{2}{|c|}{ Photograph } & \multicolumn{2}{|c|}{ Drawing } \\
\hline & I & $\mathrm{F}$ & $\mathrm{I}$ & $\mathrm{F}$ & I & $\mathrm{F}$ & $\mathrm{I}$ & $\mathrm{F}$ & I & $\mathrm{F}$ & $\mathrm{I}$ & $\mathrm{F}$ \\
\hline $\begin{array}{c}\text { Life } \\
\text { sci }\end{array}$ & 48 & 22 & 2 & 0 & 22 & 27 & 0 & 0 & 16 & 29 & 0 & 0 \\
\hline $\begin{array}{l}\text { Phys } \\
\text { sci }\end{array}$ & 19 & 0 & 0 & 0 & 0 & 0 & 0 & 0 & 0 & 0 & 0 & 0 \\
\hline $\begin{array}{c}\text { Earth } \\
\text { sci }\end{array}$ & 1 & 0 & 0 & 0 & 5 & 0 & 0 & 0 & 0 & 0 & 0 & 0 \\
\hline $\begin{array}{c}\text { Envi } \\
\text { Sci }\end{array}$ & 3 & 0 & 0 & 0 & 0 & 7 & 0 & 0 & 0 & 0 & 0 & 0 \\
\hline $\begin{array}{c}\text { Gen } \\
\text { Sci }\end{array}$ & 106 & 0 & 0 & 0 & 107 & 0 & 1 & 0 & 172 & 2 & 2 & 0 \\
\hline Total & 177 & 22 & 2 & 0 & 134 & 34 & 1 & 0 & 188 & 31 & 2 & 0 \\
\hline
\end{tabular}

The sixth research question stated that:

(6)What were the functions (decorative- doesn't support text, representational-illustrating a concept, organizational-places text within a greater scheme e.g. scale diagram, related to text) of the graphical representations in the newly developed cycle-1 primary science textbooks and workbooks? 
The answer to that question is clear from table 12 and table 13 , which show that the majority of the graphics were decorative in nature, while a small percentage were representational and organizational (related to text). It can also be seen from Tables 12 and 13 that the number of representational and organizational graphics increases as we go to higher grades. This trend was also seen by Abdel-Hameed, F. et al., for cycle 2 Science textbooks and workbooks [17].

Table 12. Distribution of the functions of graphical representations for workbooks

\begin{tabular}{|c|c|c|c|c|c|c|c|c|}
\hline \multirow{2}{*}{ Function } & \multicolumn{6}{|c|}{ Grade } & \multicolumn{2}{|c|}{ Total } \\
\cline { 2 - 10 } & \multicolumn{2}{|c|}{$\mathbf{2}$} & \multicolumn{2}{|c|}{$\mathbf{2}$} & \multicolumn{2}{|c|}{$\mathbf{3}$} & \multicolumn{2}{|c|}{} \\
\cline { 2 - 9 } & Freq & $\%$ & Freq & $\%$ & Freq & $\%$ & Freq & $\%$ \\
\hline Decorative & 501 & 82.5 & 424 & 73 & 496 & 68 & 1421 & $\mathbf{7 4 . 3}$ \\
\hline $\begin{array}{c}\text { Representat } \\
\text { ional }\end{array}$ & 58 & 9.5 & 92 & 16 & 124 & 17.7 & 274 & $\mathbf{1 4 . 3}$ \\
\hline $\begin{array}{c}\text { Organizati- } \\
\text { onal }\end{array}$ & 48 & 8 & 64 & 11 & 104 & 14.3 & 216 & $\mathbf{1 1 . 3}$ \\
\hline Total & 607 & 100 & 580 & 100 & 724 & 100 & 1911 & $\mathbf{1 0 0}$ \\
\hline
\end{tabular}

Table 13. Distribution of the functions of graphical representations for textbooks

\begin{tabular}{|c|c|c|c|c|c|c|c|c|}
\hline \multirow{3}{*}{ Function } & \multicolumn{6}{|c|}{ Grade } & \multirow{2}{*}{\multicolumn{2}{|c|}{ Total }} \\
\hline & & & & & & & & \\
\hline & Freq & $\%$ & Freq & $\%$ & Freq & $\%$ & Freq & $\%$ \\
\hline Decorative & 143 & 68.4 & 111 & 58 & 132 & 55 & 386 & 60.3 \\
\hline $\begin{array}{c}\text { Representa- } \\
\text { tional }\end{array}$ & 37 & 17.7 & 43 & 22.5 & 71 & 29.5 & 151 & 23.5 \\
\hline $\begin{array}{c}\text { Organizat- } \\
\text { ional }\end{array}$ & 29 & 13.8 & 37 & 19.4 & 37 & 15.4 & 103 & 16 \\
\hline Total & 209 & 100 & 191 & 100 & 240 & 100 & 640 & 100 \\
\hline
\end{tabular}

Regarding questions 7,

(7)What was the quality (dynamic, static) of the graphical representations in the newly developed cycle-1 primary science textbooks and workbooks?

As shown in Tables 14 and 15, the static graphics dominated in all grade levels and topic areas, with more in the lower grade levels.

Table 14. Distribution of the quality of graphical representations for textbooks

\begin{tabular}{|c|c|c|c|c|c|c|c|c|}
\hline \multirow{2}{*}{ Quality } & \multicolumn{6}{|c|}{ Grade } & \multicolumn{2}{|c|}{ Total } \\
\cline { 2 - 9 } & \multicolumn{2}{|c|}{1} & \multicolumn{2}{|c|}{2} & \multicolumn{2}{c|}{3} & \multicolumn{2}{|c|}{} \\
\cline { 2 - 9 } & Freq & $\%$ & Freq & $\%$ & Freq & $\%$ & Freq & $\%$ \\
\hline Static & 505 & 83.2 & 451 & 77.7 & 514 & 70.9 & 1470 & 76.9 \\
\hline Dynamic & 102 & 16.8 & 129 & 22.3 & 210 & 29.1 & 441 & 23.1 \\
\hline Total & 607 & 100 & 580 & 100 & 724 & 100 & 1911 & 100 \\
\hline
\end{tabular}

Table 15. Distribution of the quality of graphical representations for workbooks

\begin{tabular}{|c|c|c|c|c|c|c|c|c|}
\hline \multirow{2}{*}{ Quality } & \multicolumn{6}{|c|}{ Grade } & \multicolumn{2}{|c|}{ Total } \\
\cline { 2 - 9 } & \multicolumn{2}{|c|}{1} & \multicolumn{2}{|c|}{$\mathbf{2}$} & \multicolumn{2}{|c|}{ 3 } & \multicolumn{2}{|c|}{} \\
\cline { 2 - 9 } & Freq & $\%$ & Freq & $\%$ & Freq & \% & Freq & \% \\
\hline Static & 178 & 85 & 144 & 75.4 & 176 & 73.3 & 498 & $\mathbf{7 7 . 8}$ \\
\hline Dynamic & 31 & 15 & 47 & 24.6 & 64 & 26.7 & 142 & $\mathbf{2 2 . 2}$ \\
\hline Total & 209 & 100 & 191 & 100 & 240 & 100 & 640 & $\mathbf{1 0 0}$ \\
\hline
\end{tabular}

The last research question in this study dealt with the indexing and captioning of the graphics in various grade levels;

(8)What was the connection of the graphics, in the newly developed cycle-1 primary science textbooks and workbooks, to the written text (indexing, captioning)?

Tables 16 and 17, show the data regarding the connection of the graphics to the written text (indexing, captioning) in the newly developed cycle1 primary science textbooks and workbooks, respectively. We can see that about $65-70 \%$ of the graphics are captioned and indexed in textbooks and workbooks.

Table 16. Distribution of the indexing and captioning of graphics in textbooks

\begin{tabular}{|c|c|c|c|c|c|c|c|c|}
\hline \multirow{3}{*}{$\begin{array}{c}\text { Indexing } \\
\text { and } \\
\text { Captioning }\end{array}$} & \multicolumn{6}{|c|}{ Grade } & \multirow{2}{*}{\multicolumn{2}{|c|}{ Total }} \\
\hline & \multicolumn{2}{|c|}{1} & \multicolumn{2}{|c|}{2} & \multicolumn{2}{|c|}{3} & & \\
\hline & Freq & $\%$ & Freq & $\%$ & Freq & $\%$ & Freq & $\%$ \\
\hline Indexed & 421 & 69.3 & 415 & 71.5 & 451 & 62.3 & 1287 & 67.3 \\
\hline $\begin{array}{c}\text { Not- } \\
\text { indexed }\end{array}$ & 186 & 30.7 & 165 & 28.5 & 273 & 37.7 & 624 & 32.7 \\
\hline Captioned & 389 & 64 & 401 & 69.2 & 524 & 72.3 & 1314 & 68.7 \\
\hline $\begin{array}{c}\text { Not- } \\
\text { captioned }\end{array}$ & 218 & 36 & 179 & 30.8 & 200 & 27.6 & 597 & 31.3 \\
\hline
\end{tabular}

Table 17. Distribution of the indexing and captioning of graphics in workbooks

\begin{tabular}{|c|c|c|c|c|c|c|c|c|}
\hline \multirow{2}{*}{$\begin{array}{c}\text { Indexing } \\
\text { and } \\
\text { Captioning }\end{array}$} & \multicolumn{6}{|c|}{ Grade } & \multicolumn{2}{|c|}{ Total } \\
\cline { 2 - 9 } & Freq & $\%$ & Freq & $\%$ & Freq & $\%$ & Freq & $\%$ \\
\hline Indexed & 148 & 70.8 & 139 & 72.7 & 172 & 71.6 & 459 & $\mathbf{7 1 . 7}$ \\
\hline $\begin{array}{c}\text { Not- } \\
\text { indexed }\end{array}$ & 61 & 29.2 & 52 & 27.3 & 68 & 28.3 & 181 & $\mathbf{2 8 . 3}$ \\
\hline Captioned & 132 & 63.2 & 125 & 65.4 & 159 & 66.2 & 416 & $\mathbf{6 5}$ \\
\hline $\begin{array}{c}\text { Not- } \\
\text { captioned }\end{array}$ & 77 & 36.8 & 66 & 34.5 & 81 & 33.7 & 224 & $\mathbf{3 5}$ \\
\hline
\end{tabular}




\subsection{In-Chapter and End-of-Chapter Questions Analysis}

The objective of this part of the study was to quantify the nature, location and cognitive levels of the questions of the newly developed Cycle-1 primary science textbooks. The data for the questions categories listed in Table 3 were tabulated for each text-book on a paper matrix

The data were then entered into an excel file and descriptive statistics for each cognitive level and location of questions were calculated for each grade level.

\subsection{Research questions}

(1) What are the frequencies of the questions in the cycle-1 science textbooks, by cognitive level and chapter location?

(2) Are the percentages of high level cognitive questions consistent with the science reform expectations?

About 1584 questions were analyzed in 6textbooks in order to answer the research questions. The following tables show the analysis results:

Table 18. Classifying End-of-Chapters and InChapters Questions- Grade 1-Parts $1+2$ Student's Textbook

\begin{tabular}{|c|c|c|c|c|c|c|c|c|c|c|c|c|}
\hline \multirow{3}{*}{ Unit } & \multicolumn{12}{|c|}{ Type / level of question } \\
\hline & \multicolumn{6}{|c|}{ Formative (in-chapter) } & \multicolumn{6}{|c|}{ Summative (end-of-chapter) } \\
\hline & $\overline{\mathbf{K}}$ & $\mathbf{U}$ & $\begin{array}{l}\mathbf{A} \\
\mathbf{p}\end{array}$ & $\begin{array}{l}\mathbf{A} \\
\mathbf{n}\end{array}$ & $\mathbf{E}$ & $\begin{array}{l}\mathrm{C} / \\
\mathrm{S}\end{array}$ & $\mathbf{K}$ & $\mathbf{U}$ & $\begin{array}{l}\mathbf{A} \\
\mathbf{p}\end{array}$ & $\begin{array}{l}\mathbf{A} \\
\mathbf{n}\end{array}$ & $\mathbf{E}$ & $\begin{array}{l}\mathrm{C} / \\
\mathrm{S}\end{array}$ \\
\hline 1 & $\begin{array}{l}1 \\
2\end{array}$ & $\begin{array}{l}1 \\
4\end{array}$ & 9 & 9 & 2 & 1 & 4 & 3 & 1 & 2 & 0 & 0 \\
\hline 2 & $\begin{array}{l}1 \\
1\end{array}$ & $\begin{array}{l}1 \\
7\end{array}$ & 12 & 11 & 4 & 1 & 6 & 1 & 2 & 4 & 0 & 0 \\
\hline 3 & 7 & $\begin{array}{l}1 \\
3\end{array}$ & 4 & 7 & 3 & 9 & 9 & 2 & 1 & 1 & 2 & 2 \\
\hline 4 & 6 & $\begin{array}{l}1 \\
3\end{array}$ & 15 & 3 & 4 & 4 & 8 & 3 & 1 & 2 & 1 & 0 \\
\hline 5 & $\begin{array}{l}1 \\
1\end{array}$ & 8 & 8 & 5 & 4 & 5 & 9 & 4 & 1 & 0 & 2 & 1 \\
\hline 6 & $\begin{array}{l}1 \\
5\end{array}$ & $\begin{array}{l}1 \\
9\end{array}$ & 16 & 4 & 4 & 4 & 8 & 3 & 2 & 2 & 1 & 0 \\
\hline $\begin{array}{c}\text { Tota } \\
1\end{array}$ & $\begin{array}{l}6 \\
2\end{array}$ & $\begin{array}{l}8 \\
4\end{array}$ & 64 & 39 & $\begin{array}{l}2 \\
1\end{array}$ & 24 & $\begin{array}{l}4 \\
4\end{array}$ & $\begin{array}{l}1 \\
6\end{array}$ & 8 & 11 & 6 & 3 \\
\hline
\end{tabular}

Table 19. Classifying End-of-Chapters and InChapters Questions- Grade 2-Parts $1+2$ Student's Textbook

\begin{tabular}{|c|c|c|c|c|c|c|c|c|c|c|c|c|}
\hline \multirow{3}{*}{ Unit } & \multicolumn{12}{|c|}{ Type / level of question } \\
\hline & \multicolumn{6}{|c|}{ Formative (in-chapter) } & \multicolumn{6}{|c|}{ Summative (end-of-chapter) } \\
\hline & $\mathbf{K}$ & $\mathbf{U}$ & Ap & An & $\mathbf{E}$ & $\mathrm{C} / \mathrm{S}$ & $\mathbf{K}$ & $\mathbf{U}$ & Ap & An & $\mathbf{E}$ & $\mathrm{C} / \mathrm{S}$ \\
\hline 1 & 8 & 22 & 2 & 14 & 2 & 2 & 18 & 5 & 2 & 7 & 2 & 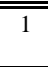 \\
\hline 2 & 5 & 13 & 6 & 15 & 2 & 3 & 13 & 4 & 5 & 8 & 2 & 3 \\
\hline 3 & 6 & 18 & 1 & 16 & 5 & 1 & 11 & 4 & 2 & 7 & 2 & 7 \\
\hline 4 & 6 & 18 & 2 & 12 & 2 & 2 & 14 & 4 & 2 & 4 & 1 & 5 \\
\hline 5 & 7 & 15 & 11 & 11 & 5 & 2 & 17 & 3 & 5 & 6 & 2 & 1 \\
\hline 6 & 6 & 13 & 3 & 10 & 6 & 1 & 12 & 14 & 3 & 2 & 1 & 3 \\
\hline Total & 38 & 99 & 25 & 78 & 22 & 11 & 85 & 34 & 19 & 34 & 10 & 20 \\
\hline
\end{tabular}

Table 20. Classifying End-of-Chapters and InChapters Questions- Grade 3-Parts $1+2$ Student's Textbook

\begin{tabular}{|c|c|c|c|c|c|c|c|c|c|c|c|c|}
\hline \multirow{3}{*}{ Unit } & \multicolumn{12}{|c|}{ Type / level of question } \\
\hline & \multicolumn{6}{|c|}{ Formative (in-chapter) } & \multicolumn{6}{|c|}{ Summative (end-of-chapter) } \\
\hline & $\mathbf{K}$ & $\overline{\mathbf{U}}$ & Ap & An & $\mathbf{E}$ & $\mathrm{C} / \mathrm{S}$ & $\bar{K}$ & $\overline{\mathbf{U}}$ & Ap & An & $\overline{\mathbf{E}}$ & $\mathbf{C} / \mathbf{S}$ \\
\hline 1 & 6 & 29 & 7 & 21 & 6 & 2 & 14 & 9 & 6 & 6 & 2 & 8 \\
\hline 2 & 4 & 27 & 17 & 10 & 0 & 3 & 8 & 16 & 13 & 1 & 0 & 0 \\
\hline 3 & 3 & 36 & 12 & 3 & 0 & 1 & 15 & 17 & 8 & 3 & 1 & 3 \\
\hline 4 & 11 & 40 & 10 & 7 & 3 & 3 & 24 & 7 & 6 & 4 & 1 & 5 \\
\hline 5 & 15 & 52 & 13 & 9 & 4 & 1 & 23 & 16 & 9 & 2 & 3 & 11 \\
\hline 6 & 4 & 63 & 6 & 7 & 1 & 0 & 16 & 11 & 6 & 5 & 0 & 12 \\
\hline Total & 43 & 247 & 65 & 57 & 14 & 10 & 100 & 76 & 48 & 21 & 7 & 39 \\
\hline
\end{tabular}

Table 21. Summary of the cognitive levels of questions in Cycle-1 primary science textbooks

\begin{tabular}{|c|c|c|c|c|c|c|}
\hline \multirow{2}{*}{\begin{tabular}{c}
\multirow{2}{*}{$\begin{array}{c}\text { Cognitive } \\
\text { categories }\end{array}$} \\
\cline { 2 - 7 }
\end{tabular}} & \multicolumn{3}{|c|}{ Percentage of total number of questions by textbook and location } \\
\cline { 2 - 7 } & Grade1 & Grade2 & Grade3 & Grade1 & Grade2 & Grade3 \\
\hline K= Knowledge & $22 \%$ & $14 \%$ & $10 \%$ & $50 \%$ & $42 \%$ & $34.5 \%$ \\
\hline U= Understanding & $28.6 \%$ & $36.3 \%$ & $56.7 \%$ & $18 \%$ & $17 \%$ & $26 \%$ \\
\hline Ap = Applications & $21.8 \%$ & $9.2 \%$ & $15 \%$ & $4 \%$ & $9.5 \%$ & $16.5 \%$ \\
\hline An= Analysis & $13.3 \%$ & $28.6 \%$ & $13 \%$ & $12.5 \%$ & $17 \%$ & $7.2 \%$ \\
\hline E= Evaluation & $7.2 \%$ & $8 \%$ & $3.2 \%$ & $7 \%$ & $5 \%$ & $2.4 \%$ \\
\hline $\begin{array}{c}\text { C/S= } \\
\text { Creativity/Synthesis }\end{array}$ & $8.2 \%$ & $4 \%$ & $2.3 \%$ & $3.5 \%$ & $10 \%$ & $13.5 \%$ \\
\hline
\end{tabular}


Using the data given in Tables 18 to 21 , the average percentages of the categories of questions for Cycle-1 Science textbooks are shown in Figure 1:

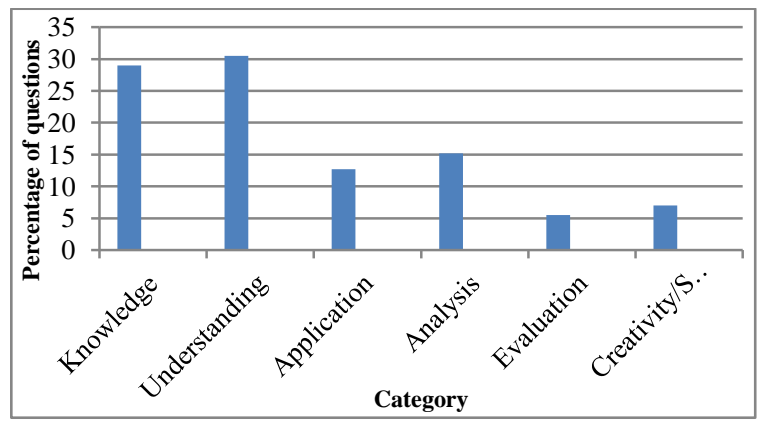

Figure 1. the distribution of questions according to their cognitive level

Analysis of school science textbooks showed that low-cognitive level questions predominate, about $73 \%$ of the questions.

Higher order thinking questions (analysis, creativity \& evaluation) make up to $27 \%$ of the questions.

Science textbook analysis, according to Kahveci Davila and Pizzini showed that:

- The input questions (knowledge \& understanding) predominate (40-45\%), which was $60 \%$ in our study;

- The processing questions (application \& analysis) come second $(35-40 \%)$, which was $28 \%$ in our study; - The output questions (synthesis, creativity \& evaluation) come last, (15-20\%), which was $12 \%$ in our study [8] [10] [20].

From our findings, about a quarter of the questions belong to higher order thinking questions, one eight belong to output questions. Therefore, the answer to our second research question is that: science textbooks are consistent with the science reform expectations to a low extent.

\section{Discussion and Further Research}

In this study, a descriptive statistical analysis of the type, function and quality of the graphical representations in 12-Bahrain cycle-1 primary science textbooks and workbooks was performed. The results of this study suggest that all graphic forms were represented.

Most forms of graphics are represented across all from topic areas of both textbooks and workbooks. About $45 \%$ of the graphics in the textbooks covered life sciences, followed by $36 \%$ for general sciences, $11 \%$ for environmental science, and $3.5 \%$ for both earth and physical sciences.

Results also showed that less than one third of the graphics were of the more analytic forms; more than one third served a specific cognitive purpose; $27 \%$ were well connected to the text; $60-70 \%$ were indexically referenced. Two third of the graphics were decorative; $76 \%$ were static representations; $30 \%$ were not indexically referenced and did not have captions.

This summation shows that graphics were primarily added to the text to make it more appealing to the teachers and students. There was an absence of maps and scale diagrams. Analysis also showed that indigenous graphics represented about $60-70 \%$ of the photographs and $60-90 \%$ of drawings. Male representations made $50-70 \%$ of the graphics.

Our study also focused on the nature, location and cognitive levels of the science textbooks questions. Results showed that $27 \%$ of the questions belong to higher order thinking questions; which indicates the newly developed science textbooks are consistent with the science curriculum reform expectations in the Kingdom of Bahrain to a certain extent.

Future work is underway, taking into account the gender equity issues, the readability level and the scientific vocabulary loads. Research is being performed in order to examine the connection between graphical representations and students' achievements and attitudes toward science, as well as analyzing the cognitive level of the questions in relation to their respective objectives.

\section{References}

[1] Koppal, M., \& Caldwell, A. (2004). Meeting the challenge of science literacy: Project 2061 efforts to improve science education. Cell Biology Education, 3 (1), 28-30.

[2] Clement, P. (2008). Critical analysis of school science textbooks. Science Education International, 19(2), 93- 96.

[3] Pingel, F. (2010). UNESCO Guidebook on Textbook Research and Textbook Revision. Paris: United Nations Educational, Scientific and Cultural Organization.

[4] Slough, S., McTigue, E., Kim, S \& Jennings, S. (2010). Science textbooks' use of graphical representations: A descriptive study of four sixth grade science texts. Reading Psychology, 31, 301- 325.

[5] Aikenhead, G.S. (1997). Towards a First Nations crosscultural science and technology curriculum. Science Education, 81, 217-238.

[6] Ninnes, P. (2000). Representations of indigenous knowledge in secondary school science textbooks in Australia and Canada. International Journal of Science Education, 22 (6), 603-617.

[7] Lee, V. R. (2010). Adaptation and continuities in the use and design of visual representations in US middle 
school science textbooks. International Journal of Science Education, 32 (8), 1099-1126.

[8] Kahveci, A. (2010). Quantitative Analysis of Science and Chemistry Textbooks for Indicators of Reform: A complementary perspective. International Journal of Science Education, 32 (11), 1495-1519.

[9] Nakiboglu, C. \& Yildirir, H.E. (2011). Analysis of Turkish High School Chemistry Textbooks and TeacherGenerated Questions about Gas Laws. Int.J. Sci. \& Math. Education, 9, 1047-1071.

[10] Davila, K. \& Talanquer, V. (2010). Classifying Endof-Chapter Questions and Problems for Selected General Chemistry Textbooks Used in the United States. Journal of Chemical Education, 87(1), 97-101.

[11] Chambliss, M. J. and Calfee, R. C. (1989) Designing science textbooks to enhance students' understanding. Educational Psychologist, 24(3), 307-322.

[12] Chiappetta, E., \& Fillman, D. (2007). Analysis of five high school biology textbooks used in the United States for inclusion of the Nature of Science. International Journal of Science Education, 29 (15), 1847-1868.

[13] Abd-El-Khalick, F., Boujaoude, S., Duschl, R., Lederman, N. G., Mamlok-Naaman, R., Hofstein, A., et al. (2004). Inquiry in science education: International perspectives. Science Education, 88, 397-419.

[14] Holliday, W.G., Whittaker, H.G. \& Loose, K.D. (1984). Differential effects of verbal aptitude and study questions on comprehension of science concepts. J. Res. Sci. Teach., 21, 140-143.

[15] Watts, G.W. \& Anderson, R.C. (1971). Effects of three types of inserted questions on learning from prose. $J$. Educ. Psychology, 62, 387-394.

[16] Leonard, W.H. (1987). J. Res. Sci. Teach., 24, 302307.

[17] Abdel-Hameed, F. \& Emara, S. (2013). Descriptive Analysis of the Graphical Representations of Cycle-2 Primary Science Textbooks in Bahrain. Literacy Information \& Computer Education Journal (LICEJ), 2(2), 1276-1283.

[18] Bloom, B.S., Krathwohl, D.R. (1956).Taxonomy of Educational Objectives, Handbook I: Cognitive Domains; Longmans Green: New York.

[19] Krathwohl, D.R. (2002). A Revision of Bloom's Taxonomy: An Overview. Theory Pract., 41, 212-218.

[20] Pizzini, E.L., Shepardson, D.P, \& Abell, S.K. (1992), The questioning level of select middle school science textbooks. School Science and Mathematics, 92(2), 74-79. 